\title{
Anatomical characteristics of teats and premilking bacterial counts of teat skin swabs of primiparous cows exposed to different types of bedding
}

\author{
J. F. Guarín, ${ }^{*}$ † C. Baumberger, ${ }^{*}$ and P. L. Ruegg*1 \\ *Department of Dairy Science, University of Wisconsin, Madison 53706 \\ †Grupo de Investigación Biogénesis, Facultad de Ciencias Agrarias, Universidad de Antioquia, Medellín, Colombia 050031
}

\begin{abstract}
Bacterial populations of teat skin are associated with risk of intramammary infection and may be influenced by anatomical characteristics of teats. The objective of this study was to evaluate associations of selected anatomical characteristics of teats with bacterial counts of teat skin of cows exposed to different types of bedding. Primarily primiparous Holstein cows $(\mathrm{n}=$ 128) were randomly allocated to 4 pens within a single barn. Each pen contained 1 type of bedding [new sand (NES), recycled sand (RS), deep-bedded manure solids (DBMS), and shallow-bedded manure solids over foam core mattresses (SBMS)]. During a single farm visit udders $(\mathrm{n}=112)$ were scored for hygiene and 1 front (n $=112)$ and 1 rear teat $(\mathrm{n}=111)$ of each enrolled cow were scored for hyperkeratosis (HK). Teat length, teat barrel diameter, and teat apex diameter were measured and teat skin swabs were systematically collected for microbiological analysis. Linear type evaluation data for udders of each cow were retrieved for each cow. Teat position (front or rear) was associated with occurrence of clinical mastitis during the 12 mo before the farm visit and more cases occurred in front quarters. The proportion of udders that were classified as clean (score 1 or 2 ) was $68,82,54$, and $95 \%$ for cows housed in pens containing NES, RS, SBMS, and DBMS, respectively. No association was found between HK score and teat position and no association was found between HK score and teat skin bacterial count. Bacterial counts of teat skin swabs from front teats of cows in pens containing RS and SBMS were significantly less than those of rear teats of cows in pens containing DBMS or NES. Teat skin bacterial counts were significantly greater for swabs obtained from teats of cows with udder hygiene scores of 3 and 4 as compared with swabs obtained from cows with cleaner udders. Of all udder conformation traits evaluated, only narrower rear teat placement
\end{abstract}

Received May 26, 2016.

Accepted October 14, 2016.

${ }^{1}$ Corresponding author: plruegg@wisc.edu was positively associated with bacterial counts on teat skin.

Key words: dairy, hygiene, hyperkeratosis, teat

\section{INTRODUCTION}

Mastitis continues to be the most common and economically important disease of dairy cows located in developed dairy regions (Seegers et al., 2003; Ruegg and Erskine, 2014). Mastitis is an inflammation of the udder that usually occurs in response to IMI after pathogenic microorganisms enter through the teat canal (Hogan et al., 1999). According to Vanderhaeghen et al. (2015) bacteria can be classified as host-adapted versus environmental and as contagious versus opportunistic. Contagious bacteria originate from infected quarter(s) and spread among cows (usually via a fomite) whereas opportunistic bacteria have multiple sources (usually in the environment). In North America, the widespread adoption of modern management practices has resulted in an overall decrease in prevalence of IMI and a greater proportion that are caused by opportunistic (rather than contagious) pathogens (Makovec and Ruegg, 2003; Pinzón-Sánchez and Ruegg, 2011; Schukken et al., 2011). Prevention of environmental mastitis is based on reduction of exposure of teats and ensuring excellent udder hygiene. Dairy cattle spend 12 to 14 $\mathrm{h}$ per day lying down (Tucker and Weary, 2004), and during this time their teats are intimately exposed to potential pathogens in their environment (Hogan et al., 1989). The risk of IMI has been previously associated with teat dimensions (Slettbakk et al., 1995; Zwertvaegher et al., 2013). In a recent case-control study, we demonstrated that increased diameter of the teat apexes of front teats was associated with increased risk of clinical mastitis (Guarín and Ruegg, 2016). Likewise, for front (but not rear) teats, we recently observed that greater diameter of the teat apexes was associated with increased SCC (Guarin et al., 2017). These associations may indicate that front teats with wider apexes have reduced ability to resist IMI caused by opportunistic bacteria and emphasize the importance of understanding 
the magnitude of bacterial exposure based on bedding type. The relationship of teat dimensions with bacterial counts of teat skin and possible relationship with IMI is not well defined. The objective of the current study was to evaluate potential associations of selected teat anatomical characteristics with bacterial counts of teat skin swabs obtained from primiparous cows exposed to different types of bedding.

\section{MATERIALS AND METHODS}

\section{Herd Selection}

This study was conducted at the University of Wisconsin-Madison, Marshfield Research Station and was approved by the Animal Care and Use Committee at the University of Wisconsin-Madison (Protocol \# A-01488). Details of the freestall barn, bedding, and the cows' diet have been previously described (Rowbotham and Ruegg, 2016). In brief, the freestall barn contains 4 equally sized pens each containing 32 head-to-head stalls. Each of the 4 pens contained a single type of bedding material: deep-bedded new sand (NES), deepbedded recycled sand (RS), deep-bedded manure solids (DBMS), or shallow-bedded manure solids over foam core mattresses (SBMS). Manure was removed from stalls twice daily and bedding was added to the back of the stalls twice weekly. This facility is part of other ongoing environmental studies and contains primarily primiparous Holstein cows. The pens accommodate up to 32 cows each (maximum of 128 cows) and occasionally if the pens are not full, a few multiparous cows are moved to that facility to maintain cow numbers for the other studies.

\section{Sample Collection and Randomization}

Except for the linear type data that were based on evaluations performed by classifiers of the Holstein Association, 2 researchers (J. F. Guarín and C. Baumberger) collected all data and performed all measurements during a single farm visit. Before premilking teat preparation, data were collected by (1) assigning an udder hygiene score (UHS), (2) swabbing teats, and (3) measuring teat dimensions (from the same teats that were swabbed). The milking technician then completed premilking preparation and attached the milking unit. After the milking units were automatically detached (4) hyperkeratosis scores were assigned (from the same teats that were swabbed and measured). After all animal observations were collected, (5) cow data were extracted from herd management software (DairyComp 305, Valley Agricultural Software, Tulare, CA) and (6) a representative bedding sample was collected from each of the 4 evaluated pens.

Udder hygiene scoring was performed as described by Schreiner and Ruegg (2003) on 111 primiparous cows and 1 second-lactation cow, which were evenly distributed in the 4 pens. Teat skin swabs were collected from all enrolled teats $(n=224)$ of 28 cows per pen by the same experienced researcher (C. Baumberger) after cows entered the parlor but before premilking teat sanitation. Teats were sequentially enrolled using the sequence: left front and right rear, or right front and left rear. Skin of 1 front and 1 rear teat of 28 cows in each of the 4 pens was systematically swabbed using a single sterile rolled-gauze swab $(10.2 \times 10.2 \mathrm{~cm})$ moistened in buffered peptone water (Becton, Dickinson and Company, Sparks, MD) for each teat, as previously described by Baumberger et al. (2016). In brief, the bottom $2 \mathrm{~cm}$ of one side of the teat was wiped, followed by rotating the swab around the teat apex and swabbing the bottom $2 \mathrm{~cm}$ of the other side of the teat. The swab was immediately immersed in $4 \mathrm{~mL}$ of buffered peptone water and maintained on ice until it arrived at the University of Wisconsin Milk Quality laboratory for microbiological analysis.

Teat dimensions of all enrolled cows $(\mathrm{n}=112)$ were measured by a single researcher (J. F. Guarín) before unit attachment, as previously described (Guarín and Ruegg, 2016). Briefly, the length, barrel diameter, and teat apex diameter were measured using a translucent measuring ruler with a scale unit of $2 \mathrm{~mm}$, which illuminated the teats with a white lamp (WestfaliaSurge, Inc., Naperville, IL). All measurements were video recorded using a GoPro HERO3 camera (GoPro Inc., San Mateo, CA).

Hyperkeratosis scores were determined using a 4-point scale as no ring (N), smooth or slight ring $(\mathbf{S})$, rough ring $(\mathbf{R})$, very rough ring (VR; Mein et al., 2001). Parity, DIM, DHIA SCS, 305-d milk production, and health events of each cow $(\mathrm{n}=112)$ were collected from herd management software (Dairy Comp 305; Valley Agricultural Software). Clinical mastitis cases were defined as the production of abnormal milk with or without secondary symptoms. This definition was used by the trained milking technicians at the Marshfield Research Station of the University of Wisconsin who detected mastitis during premilking preparations and recorded all the information and outcomes of the disease at the quarter level.

Linear type data based on evaluations performed by classifiers of the Holstein Association (http://holsteinusa.com) were available for 103 animals and used to assess potential associations of several udder conformation traits with teat skin bacterial count. The linear 
type evaluations were performed 2 mo before collection of other data (December 2014). Linear type traits were scored individually, using a scale from 1 to 50 points (http://www.holsteinusa.com/genetic_evaluations/ ss_interpret_linear.html). Linear type traits (and recommended goals) included fore udder attachment (FU; $>35$ points desirable), rear udder height $(\mathbf{U H} ;>30$ points desirable), rear udder width (UW; $>30$ points desirable), udder cleft (UC; includes differences in the depth of the cleft between rear quarters at the bottom of the udder; between 20 and 45 points desirable), udder depth (UD; $>30$ points desirable), front teat placement (FT; between 20 and 40 points desirable), rear teat placement (RT; around 25 is intermediate, 1 extremely wide, and 50 indicates that teats are crossed), and teat length (TL; genetic differences in the length of longest teat; between 10 and 40 points desirable). Linear type traits were expressed as standardized transmitting abilities (STA), where a zero (0.0) STA represents the average for that trait.

During the same farm visit a sample of bedding ( $\mathrm{n}$ $=4$ ) was collected from each of the 4 pens. Composite samples were collected from randomly assigned stalls in each of the 4 pens. Small amounts of bedding, about $30 \mathrm{~g}$ each, were collected in a stainless steel bucket and mixed to obtain a final sample of about 300 to $500 \mathrm{~g}$ of bedding. Immediately after, samples were cooled until processed at the University of Wisconsin-Madison Milk Quality Laboratory.

\section{Laboratory Procedures}

Teat Skin Swabs. In the laboratory, moisture was extracted from teat swabs and used to make 4 serial dilutions from 1:10 to $1: 100,000$. This range was selected based on preliminary testing of 32 samples that indicated this range was appropriate to estimate total bacterial count (TBC). Each dilution was inoculated onto Petrifilm Total Aerobic Count plates (3M, St. Paul, MN), following the manufacturer's instructions, incubated for $48 \mathrm{~h}$ at $32^{\circ} \mathrm{C}$, and then counted using a Petrifilm Plate Reader (3M).

Bedding Samples. The number of gram-negative noncoliform bacteria, coliforms, Klebsiella spp., Streptococcus spp., and Staphylococcus spp. in bedding samples was estimated using a previously described method (Hogan et al., 1989; Rowbotham and Ruegg, 2016). Briefly, 1:10 dilutions were prepared by suspending 10 $\mathrm{g}$ of each of the 4 bedding samples in $90 \mathrm{~mL}$ of sterile PBS. After dilutions were made, they were manually shaken for $60 \mathrm{~s}$ and allowed to settle to permit pipetting of the liquid. Bacterial colonies were enumerated using previously described methods that involved plat- ing serial dilutions onto selective agar medium (Hogan et al., 1989). Briefly, duplicate serial dilutions of the liquid were prepared and four $10-\mu \mathrm{L}$ inoculations of each duplicate dilution $\left(1: 10^{1}\right.$ to $\left.1: 10^{5}\right)$ were plated on 4 selective agars. MacConkey agar (Becton, Dickinson and Company, Sparks, MD) was used to enumerate gram-negative noncoliform bacteria. Coliforms and lactose-fermenting colonies were defined as coliforms, whereas colorless colonies were defined as gramnegative noncoliform bacteria. MacConkey-inositolcarbenicillin agar, Edwards modified agar (Oxoid Ltd., Basingstoke, UK) containing 5\% bovine plasma, and Baird-Parker agar (Becton, Dickinson and Company) were used to enumerate Klebsiella spp., Streptococcus spp., and Staphylococcus spp., respectively. The plates were incubated overnight at $37^{\circ} \mathrm{C}$. After incubation, for each bacterial type, the plate with the least dilution that contained countable ( $\leq 50 \mathrm{cfu} /$ inoculation) colony-forming units was enumerated. The average number of colonies from each duplicate dilution was calculated as the mean number of colonies on the four $10-\mu \mathrm{L}$ inoculations. The final number of colonies was the mean of the average number of colonies from the 2 duplicate dilutions. To determine DM content on the bedding sample, 75 to $500 \mathrm{~g}$ of each bedding sample was placed in a convection oven for $48 \mathrm{~h}$ at $55^{\circ} \mathrm{C}$. The difference in weight between initial and post-48-h dehydrated sample denoted the humidity content of the bedding.

\section{Statistical Analysis}

Statistical analyses were performed using SAS version 9.3 (SAS Institute, 2011) and significance was declared at $P \leq 0.05$. Descriptive analyses were performed for all data using PROC UNIVARIATE or PROC FREQ to verify data accuracy and to examine frequency distributions. Continuous variables were categorized and summarized using the PROC MEANS. To normalize the distribution of bacterial counts on teat skin swabs and on bedding samples results, all bacterial counts were transformed to $\log _{10}$ for analyses. Somatic cell scores were calculated from the most recent DHIA SCC test using the formula $\mathrm{SCS}=\log _{2}(\mathrm{SCC} / 100)+3$, as described by Shook (1993).

With the aim of comparing front versus rear teat segments of each animal, paired samples $t$-tests were performed using the PROC TTEST between each of the measured segments of the teats of each animal. The PROC FREQ was used to perform a $\chi^{2}$ test to evaluate the null hypothesis that the proportion of HK scores was equally distributed between front and rear quarters. 
Multivariate models were constructed following the process described by Dohoo et al. (2003). Briefly, biologically plausible explanatory variables for each of the models were tested, and only those unconditionally associated with the response variable of each model at $P$ $\leq 0.25$ were first introduced into a full model and then removed (or re-entered) into the model using manual backward stepwise modeling. To avoid multicollinearity, highly correlated explanatory variables were determined using correlation coefficients calculated using PROC CORR, and those variables were not allowed to enter in the multivariable modeling process together. Confounding and interaction terms were tested while building the models. Only variables at $P \leq 0.05$ were retained in the model.

A mixed model (PROC MIXED) was used to determine possible associations between HK scores and bacterial counts on teat skin. Hyperkeratosis score and DIM were included in the model as fixed effects, and cow was used as a random term to account for the clustering of cow within each pen.

Model 1 was constructed to test the null hypothesis that premilking bacterial counts of teat skin are not associated with anatomical characteristics of the teat. Data were analyzed using the PROC MIXED with quarter within cow as the unit of analysis. The model was corrected for within-pen clustering using cow as a random effect. Position of the quarter within cow was used as a repeated measurement (compound symmetry) to account for the possible correlation among quarter position (front or rear) within cow. Multiple comparisons were performed using a $P$-value adjusted using Tukey's method. Manual, backward stepwise modeling was used to eliminate terms from the initial model. The initial linear mixed model 1 used was

$$
\begin{aligned}
& \log _{10} \mathrm{TBC}_{\mathrm{ijklmnopq}}=\mu+\text { Pen }_{\mathrm{i}}+{\text { Quarter } \text { Position }_{\mathrm{j}}} \\
& + \text { Pen } \times \text { Quarter Position } \\
& \mathrm{ij}
\end{aligned}
$$

where response variable $\log _{10} \mathrm{TBC}_{\mathrm{ijklmnopq}}=\log _{10}$-transformed total bacterial count on teat skin and $\mu=$ overall mean. Random effects were $\operatorname{Cow}(\mathrm{Pen})_{\mathrm{iq}}=\mathrm{cow}$ within pen as a random variable, and Quarter Position $(\mathrm{Cow})_{\mathrm{ij}}$ $=$ compound symmetry to account for the correlation among quarters within cow. Fixed effects were $\mathrm{Pen}_{\mathrm{i}}$ = type of bedding ( $\mathrm{i}$ is NES, RS, DBMS, or SBMS); Quarter Position $_{\mathrm{j}}=$ quarter position ( $\mathrm{j}$ is front or rear);

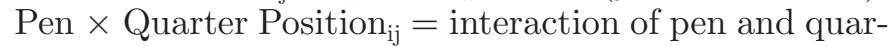
ter position; Length $\mathrm{k}_{\mathrm{k}}=$ length of the teat (expressed as $\mathrm{k}$ in $\mathrm{mm}$ ); Barrel $_{1}=$ diameter of the barrel (expressed as 1 in $\mathrm{mm}$ ); and Apex $_{\mathrm{m}}=$ diameter of the teat apex (expressed in $\mathrm{mm}$ ).
Model 2 was used to test the null hypothesis that, after controlling for bedding type, the average premilking bacterial counts of teat skin swabs obtained from front and rear teats of each cow was not associated with UHS or selected udder conformation traits. Teat skin bacterial counts were collapsed to the cow level by averaging the bacterial counts of front and rear teats of each cow. Data were analyzed using the PROC MIXED with cow as the unit of analysis. The model used pen as random effect to account for the random effect of the different beddings. Multiple comparisons were performed using a $P$-value adjusted following Tukey testing. Manual, backward stepwise modeling was used to eliminate terms from the initial model.

The initial linear mixed model 2 used was

$$
\begin{gathered}
\log _{10} \text { MeanTBC }_{\mathrm{ijklmnopqr}}=\mu+\mathrm{UHS}_{\mathrm{i}}+\mathrm{FU}_{\mathrm{j}}+\mathrm{UH}_{\mathrm{k}} \\
+\mathrm{UW}_{\mathrm{l}}+\mathrm{UC}_{\mathrm{m}}+\mathrm{UD}_{\mathrm{n}}+\mathrm{FT}_{\mathrm{o}}+\mathrm{RT}_{\mathrm{p}} \\
+\mathrm{TL}_{\mathrm{q}}+\mathrm{Pen}_{\mathrm{r}}+\varepsilon_{\mathrm{ijklmnopqr}}
\end{gathered}
$$

where the response variable $\log _{10} \mathrm{MeanTBC}_{\mathrm{ijklmnopqr}}=$ $\log _{10}$-transformed average total bacterial count on teat skin of front and rear teats of each cow and $\mu=$ overall mean. Random effects were $\mathrm{Pen}_{\mathrm{r}}=$ type of bedding as a random variable ( $\mathrm{r}$ is NES, RS, DBMS, or SBMS). Fixed effects were $\mathrm{UHS}_{\mathrm{i}}=$ hygiene score of the udder (i is $1,2,3$, or 4$) ; \mathrm{FU}_{\mathrm{j}}=$ genetic differences in the strength, firmness, and shape of the fore udder attachment to the body wall ( $\mathrm{j}$ indicates the STA of the trait); $\mathrm{UH}_{\mathrm{k}}=$ genetic differences in the distance between the bottom of the vulva and the top of the rear udder attachment ( $\mathrm{k}$ indicates the STA of the trait); $\mathrm{UW}_{1}=$ genetic differences in the distance across the rear udder at the point of attachment (1 indicates the STA of the trait); $\mathrm{UC}_{\mathrm{m}}$ $=$ genetic differences in the depth of the cleft between rear quarters at the bottom of the udder ( $\mathrm{m}$ indicates the STA of the trait); $\mathrm{UD}_{\mathrm{n}}=$ genetic differences in the distance between lowest point of udder floor and point of the hock (n indicates the STA of the trait); $\mathrm{FT}_{\mathrm{o}}=$ genetic differences in the distance between the base of the front teats (o indicates the STA of the trait); $\mathrm{RT}_{\mathrm{p}}$ $=$ genetic differences in the distance between the rear teats as viewed from behind ( $p$ indicates the STA of the trait); $\mathrm{TL}_{\mathrm{q}}=$ genetic differences in the length of longest teat (q indicates the STA of the trait); and $\varepsilon_{\mathrm{ijklmnopqr}}=$ residual random error.

A binomial test was used to determine if the proportion of clinical mastitis (CM) cases occurring in the previous calendar year (Jan 1 to Dec 31 2014) was equally distributed between front and rear quarters. The sample size provided an excess of $95 \%$ confidence and $80 \%$ power to detect 0.7 log-unit differences in the $\log _{10}$-transformed bacteria among different beddings. 
Table 1. Descriptive characteristics of teats and cows enrolled $(\mathrm{n}=111$ primiparous and 1 multiparous cow $)$

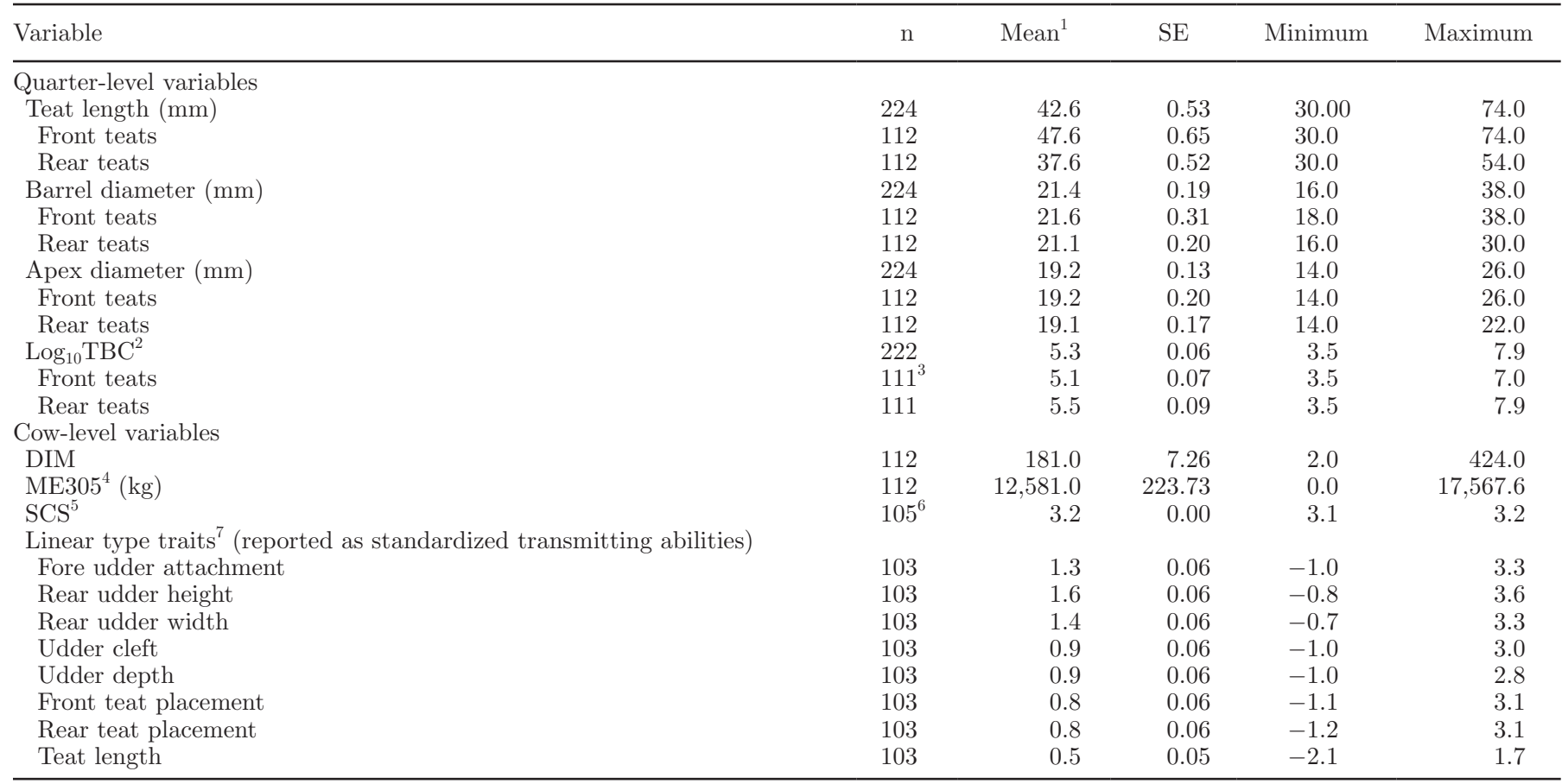

${ }^{1}$ Mean $=$ values are arithmetic mean unless otherwise indicated

${ }^{2} \log _{10} \mathrm{TBC}=\log _{10}$-transformed total bacterial count on teat skin $/ \mathrm{mL}$.

${ }^{3}$ Data from 1 teat not available.

${ }^{4}$ ME305 = adjusted 305-d milk production.

${ }^{5} \mathrm{SCS}=$ average SCS of most recent DHIA test on somatic cells.

${ }^{6}$ Data from 7 cows were not available.

${ }^{7}$ Linear type traits $=$ standardized transmitting abilities $(\mathrm{STA})$ of the udder and teat type traits, where: 0.0 is the average STA of the trait, \pm 1.0 cover $68 \%$ of the STA values, \pm 2.0 cover $95 \%$ of the STA values, and \pm 3.0 cover $99 \%$ of the STA values. Data were not available for 9 cows.

\section{RESULTS AND DISCUSSION}

One front $(\mathrm{n}=112)$ and 1 rear teat $(\mathrm{n}=111)$ of each enrolled cow $(\mathrm{n}=112)$ were swabbed, scored for HK, and measured. One rear teat was not functional and not measured or scored for HK. The arithmetic average DIM, SCS, and 305-d projected milk were 181 $\pm 7 \mathrm{~d}, 3.2 \pm 0.001$, and $12,580 \pm 224 \mathrm{~kg}$, respectively (Table 1).

The DM $(\%)$ and TBC $\left(\log _{10} \mathrm{cfu} / \mathrm{mL}\right)$ were $90 \%$ and $7.1 \log _{10} \mathrm{cfu} / \mathrm{mL}, 91 \%$ and $7.1 \log _{10} \mathrm{cfu} / \mathrm{mL}, 49 \%$ and $7.8 \log _{10} \mathrm{cfu} / \mathrm{mL}$, and $48 \%$ and $7.4 \log _{10} \mathrm{cfu} / \mathrm{mL}$ for bedding samples collected from pens containing NES, RS, SBMS, and DBMS, respectively. The results of coliform counts of bedding samples were 3.2, 3.1, 4.3, and $5.1 \log _{10} \mathrm{cfu} / \mathrm{mL}$ for NES, RS, SBMS, and DBMS, respectively. The noncoliform gram-negative counts of bedding were $4.8,5.1,5.6$, and $6.2 \log _{10} \mathrm{cfu} / \mathrm{mL}$ for NES, RS, SBMS, and DBMS, respectively. The majority of isolates in bedding samples were Streptococcus spp., and were $7.1,7.1,7.8$, and $7.3 \log _{10} \mathrm{cfu} / \mathrm{mL}$ for NES, RS, SBMS, and DBMS, respectively. Results for
Klebsiella spp. from bedding samples were 3.0, 3.2, 3.1, and $5.0 \log _{10} \mathrm{cfu} / \mathrm{mL}$ for NES, RS, SBMS, and DBMS, respectively. These counts were similar to values previously reported based on weekly serial bedding cultures performed in the same pens over a 1-yr period (Rowbotham and Ruegg, 2016).

Of CM occurring in $2014(\mathrm{n}=86)$, the proportion of cases that occurred in front $(56.1 \%)$ versus rear quarters $(44.9 \%)$ differed $(P<0.001)$ from a hypothesized $50 \%$ distribution of cases between front and rear quarters. Of all cases of CM, farm personnel collected and submitted milk samples from only 53 to our University of Wisconsin-Madison Milk Quality Laboratory. The distribution of culture results was $35.8 \%$ gram-positive bacteria (1 case of Staphylococcus aureus), 30.1\% gramnegative, $30.1 \%$ no microbial growth, and 2 yeast. The most frequent organisms recovered were environmental streptococci and Escherichia coli. This distribution of pathogens was similar to previous studies that have been conducted in Wisconsin but had a slightly greater proportion of gram-positive organisms (Pinzón-Sánchez and Ruegg, 2011; Oliveira et al., 2013). Mastitis caused 
by contagious organisms such as Streptococcus agalactiae or Staph. aureus are not common in Wisconsin farms, because most farms have successfully implemented control plans against these pathogens (Ruegg, 2012).

The system of classification of teat ends used in our study was developed by Neijenhuis et al. (2001b) and adapted into a simpler 4-point scale for field scoring by Mein et al. (2001). The 4-level classification system is used to identify increased degrees of teat end callosity. A very rough surface at the teat end may be more difficult to clean during premilking preparation and provide a site for bacterial colonization, potentially leading to increased risk of IMI (Mein et al., 2001). Of 223 teats scored for HK, $70 \%(\mathrm{n}=156)$ were scored $\mathrm{N}$, $11 \%(\mathrm{n}=25)$ were scored smooth or $\mathrm{S}, 17 \%(\mathrm{n}=38)$ were scored $\mathrm{R}$, and only $2 \%(\mathrm{n}=4)$ were scored VR. Score $\mathrm{N}$ was the most frequent score from cows in this population and indicated that most cows had healthy teat ends. The proportion of score R (17\%) and score VR $(2 \%)$ were well within acceptable limits for these undesirable scores $(<20 \% \mathrm{R}$ and $\mathrm{VR}$, and $<10 \% \mathrm{VR}$, respectively; Ruegg, 2011). No association was found between teat HK score and quarter position $\left(\chi^{2}=\right.$ $0.656)$ and no association was observed between HK scores and teat skin bacterial count $(P=0.757)$, but the prevalence of undesirable scores was very low. Previous work by our group (Guarin et al., 2017), which included a greater number of herds and cows, indicated that teats with scores of VR are associated with greater quarter SCC. Neijenhuis et al. (2001a) studied 15 farms in the Netherlands consisting of 2,157 cows and determined that cows with CM had greater HK scores than herd mates and the association of $\mathrm{HK}$ and $\mathrm{CM}$ varied among pathogens. Cow with rougher teat end HK had more infections that were culture-negative or caused by pathogens such as yeast, Klebsiella pneumoniae, and Enterobacter aerogenes, whereas cases caused by Escherichia coli were associated with lesser teat end callosity.

In the current experiment, the vast majority of $\mathrm{HK}$ scores were $\mathrm{N}$ or $\mathrm{S}$ and had no association with teat skin bacterial count. We hypothesize that the association of bacterial counts on teat skin and HK score was not evident in the current study due to the low prevalence of teats scored VR, mainly because most animals were primiparous and were milked in the same milking parlor and are subjected to the same milking machine settings. More research on this subject is required, especially including multiparous animals at different stages of lactation, different bedding types, and different seasons in the experimental design.

As compared with rear teats, front teats were longer $(\mathrm{t}=17.31 ; P \leq 0.001)$. We noted a tendency for front teats to be wider at the teat barrel $(\mathrm{t}=1.75 ; P=$ $0.083)$, but not at the apex $(\mathrm{t}=0.39 ; P=0.700)$. These results agree with previous results for teat length but differ from our previous results for teat barrel diameter (Guarín and Ruegg, 2016). The mean (SE) teat length [42.6 (0.53) mm], teat barrel diameter [21.4 (0.19) $\mathrm{mm}]$, and width of teat apex [19.2 $(0.13) \mathrm{mm}]$ measured in the current study (Table 1) are similar to data of primiparous cows previously obtained by our research team (Guarin et al., 2017) in a larger cross-sectional study. In that study (Guarin et al., 2017), teats of primiparous cows $(\mathrm{n}=618)$ had mean $(\mathrm{SE})$ length of $42.8(0.30) \mathrm{mm}$, barrel diameter of $22.7(0.10) \mathrm{mm}$, and teat apex diameter of $19.3(0.8) \mathrm{mm}$. As compared with the previous cross-sectional study (Guarin et al., 2017), similar dimensions of front and rear teats were also separately observed, although the diameter of both front and rear teat barrels of cows enrolled in the previous cross sectional study appeared to be about 1 to 1.5 mm wider.

Mastitis risk is dependent on exposure to pathogenic bacteria and on the efficiency of host immunity (Pyörälä, 2002). Bacterial numbers on teat skin are indicative of increased potential exposure, but other mechanisms may be necessary for exposure to result in IMI. Among these, larger teat orifices and wider teat canals (Seykora and McDaniel, 1985), wider teat apexes of front teats (Guarín and Ruegg, 2016), or milking machine-induced changes on teats (Zwertvaegher et al., 2013) have been associated with increased risk of IMI.

Of 112 cows, 224 teat skin swabs were collected. From these, 2 samples (1 front and 1 rear, obtained from cows in pen $\mathrm{RS}$ ) were unusable because of problems during their transportation and processing at the laboratory. These samples were not included in the analysis. Teat dimensions were not associated with increased teat skin bacterial counts and were eliminated from model 1 (Table 2). The quantity of bacteria was greater for teat skin swabs obtained from rear teats $(5.5 \pm 0.09$ $\log _{10}$ TBC of teat skin) as compared with front teats $\left(5.1 \pm 0.07 \log _{10}\right.$ TBC of teat skin; Table 1$)$. In model 1 , a significant interaction between position and pen was identified $(P=0.048$; Table 2$)$. Least squares means of TBC of teat skin swabs for front teats of cows in pens containing RS and SBMS were significantly lesser than counts for rear teats of cows in pens containing DBMS or NES (Table 2). Within bedding type, except for cows in the pen containing NES, TBC of teat skin swabs did not vary based on teat position (Table 2). For cows housed in the pen containing NES, TBC of teat skin swabs obtained from rear teats was greater than that of swabs obtained from front teats (Table 2 ). During the herd visit, very little bedding was present on the foam-core mattresses in the pen containing 
Table 2. Model 1: Final generalized linear mixed model for $\log _{10}$-transformed bacterial count on teat skin and selected teat anatomical characteristics of cows exposed to different bedding types $(\mathrm{n}=222,2$ observations not used)

\begin{tabular}{|c|c|c|c|c|c|}
\hline Predictor & $\begin{array}{l}\text { Quarter } \\
\text { position }\end{array}$ & Coefficient $\beta$ & $\mathrm{SE}(\beta)$ & $P$-value & $\begin{array}{l}\text { Variance } \\
\text { components }\end{array}$ \\
\hline Intercept & & 5.02 & 0.16 & $<0.001$ & \\
\hline Quarter Position $^{2}$ & & & & $<0.001$ & \\
\hline Pen $\times$ Quarter Position & & & & 0.048 & \\
\hline \multirow[t]{2}{*}{ NES } & Front & $5.13^{\mathrm{bc}}$ & 0.15 & & \\
\hline & Rear & $5.90^{\mathrm{a}}$ & 0.15 & & \\
\hline \multirow{2}{*}{ DBMS } & Front & $5.36^{\mathrm{abc}}$ & 0.15 & & \\
\hline & Rear & $5.64^{\mathrm{ab}}$ & 0.15 & & \\
\hline \multirow[t]{2}{*}{ SBMS } & Front & $4.93^{\mathrm{c}}$ & 0.15 & & \\
\hline & Rear & $5.02^{\mathrm{bc}}$ & 0.15 & & \\
\hline Cow(Pen) & & & & & 0.235 \\
\hline Compound Symmetry - Quarter Position(Cow) & & & & & 0.421 \\
\hline
\end{tabular}

${ }^{a-c}$ Estimates for the interaction pen by quarter position with different superscripts differ statistically $(P<0.05)$.

${ }^{1}$ Pen $=$ NES (deep-bedded new sand), RS (deep-bedded recycled sand), DBMS (deep-bedded manure solids), SBMS (shallow-bedded manure solids over mattresses with a foam core).

${ }^{2}$ Front or rear.

SBMS and likely influenced bacterial exposure of teats of cows present in these pens. We suspect that because the amount of organic bedding in the SBMS was very scarce, the bacterial counts of teat skin of cows in this pen may not have reflected bacterial counts actually present in the manure-based bedding.

Although the number of teat skin bacteria was greater for rear teats compared with front teats, the detected incidence of $\mathrm{CM}$ in the previous calendar year was greater for front quarters as compared with rear quarters. This suggests that the incidence of $\mathrm{CM}$ is likely related to other important risk factors that might affect the front and rear teats differently, such as disparities in teat preparation, incidence of liner slips due to unit alignment problems, or deficiencies in cleaning front teats (as compared with rear) in parallel parlors (rather than magnitude of exposure to potential pathogens on the teat skin). Previous research conducted using the same herd of predominantly primiparous cows indicated a tendency for longer survival times to incidence of $\mathrm{CM}$ for cows in pens containing NES or DBMS, but the overall incidence of subclinical and clinical mastitis did not vary based on bedding type (Rowbotham and Ruegg, 2016). In all instances, it is important to recognize that these studies were conducted using primiparous cows, which are known to have reduced risk of CM as compared with older cows (Pinzón-Sánchez and Ruegg, 2011). Our study design did not allow us to assess bedding-associated risks of mastitis for multiparous cows; future research should be directed toward elucidation of parity-specific risks of exposure to various bedding sources.
In our study, among linear type variables of the udder, only rear teat placement remained in model 2 with increased bacterial counts on teat skin associated with more narrow teat placement $(P=0.048$; Table 3$)$. Of scored udders, the distribution of UHS was 26.7 (UHS 1), 46. 7 (UHS 2), 15.2 (UHS 3), and 11.4\% (UHS 4). The proportion of UHS differed among pens $\left(\chi^{2}\right.$ with $3 \mathrm{df}=63.14, P<0.001)$. The pen containing SBMS contained the greatest proportion of udders with UHS 3 and $4(46 \%)$ as compared with 32,18 , and $5 \%$ of cows in pens NES, RS, and DBMS, respectively. Increased UHS was positively associated with increased bacterial counts of teat skin $(P=0.002$; Table 3$)$. In the current study, cows with UHS 3 and 4 had greater bacterial counts on teat skin than cows with score 1 , and cows with UHS scored 2 showed intermediate values of bacterial counts in teat skin (Table 3). As demonstrated by Schreiner and Ruegg (2003), dirtier udder hygiene is associated with increased risk of IMI and subclinical mastitis. Cows with UHS 3 and 4 were 1.5 times more likely of developing IMI than cows scored 1 or 2 .

\section{CONCLUSIONS}

In conclusion, bacterial numbers on teat skin were associated with position (rear vs. front), but an interaction with bedding type was found. After analyzing data with a multivariate model, except for teats of cows on NES (which had greater TBC on rear teats), TBC of teat skin swabs was generally similar for front and rear teats but the incidence of clinical mastitis in cows was greater in front quarters than in rear quarters, indi- 
Table 3. Model 2: Final generalized linear mixed model for mean $\log _{10}$-transformed bacterial count on teat skin and selected cow-level variables for cows exposed to different bedding types $(\mathrm{n}=96,16$ observations not used)

\begin{tabular}{lcccc}
\hline Predictor & Coefficient $\beta$ & SE $(\beta)$ & $P$-value & $\begin{array}{c}\text { Variance } \\
\text { components }\end{array}$ \\
\hline Intercept $_{\text {Udder hygiene scores }}{ }^{1}$ & 4.79 & 0.19 & $<0.001$ & \\
$\quad 1$ & & & 0.002 & \\
2 & $4.90^{\mathrm{b}}$ & 0.18 & \\
3 & $5.25^{\mathrm{ab}}$ & 0.16 & \\
$\quad$ Rear teat placement $^{2}$ & $5.53^{\mathrm{a}}$ & 0.22 & & \\
Pen $^{3}$ & 0.14 & 0.24 & 0.048 & \\
Residual $^{\mathrm{a}}$ & & & & \\
\end{tabular}

${ }^{\mathrm{a}, \mathrm{b}}$ Estimates for the udder hygiene scores with different superscripts differ statistically $(P<0.05)$.

${ }^{1}$ Udder hygiene scores $=1$ (clean), 2 (dip present, no dirt or manure present $2-10 \%$ of surface covered), 3 (small amount of dirt and manure present $10-30 \%$ of surface covered), and 4 (large amount of dirt and manure present $>30 \%$ of surface covered).

${ }^{2}$ Rear teat placement $=$ udder conformation trait for rear teat placement, expressed as standardized transmitting abilities.

${ }^{3}$ Pen $=$ NES (deep-bedded new sand), RS (deep-bedded recycled sand), DBMS (deep-bedded manure solids), SBMS (shallow-bedded manure solids over mattresses with a foam core).

cating that risk factors other than bacterial counts of teat skin may be involved in development of mastitis. No association of teat dimensions and teat skin bacterial counts was identified. An association of UHS with teat skin bacterial counts was found and cows that had dirtier udders also had greater bacterial counts on teats. Udder conformation trait for rear teat placement was positively associated with bacterial counts on teat skin, and more closely placed rear teats had increased bacterial counts.

\section{ACKNOWLEDGMENTS}

The researchers thank the personnel at the Marshfield Agricultural Research Station (Marshfield, WI) for all the help they provided during the planning and execution of this project, especially to Nancy Esser, assistant superintendent of this farm.

\section{REFERENCES}

Baumberger, C., J. F. Guarin, and P. L. Ruegg. 2016. Effect of 2 different premilking teat sanitation routines on reduction of bacterial counts on teat skin of cows on commercial dairy farms. J. Dairy Sci. 99:2915-2929.

Dohoo, I., W. Martin, and H. Stryhn. 2003. Veterinary Epidemiologic Research. AVC Inc., Charlottetown, PEI, Canada.

Guarin, J. F., M. G. Paixao, and P. L. Ruegg. 2017. Association of anatomical characteristics of teats with quarter milk somatic cell count. J. Dairy Sci. 100:643-652. https://doi.org/10.3168/ jds.2016-11459.

Guarín, J. F., and P. L. Ruegg. 2016. Short communication: Pre- and postmilking anatomical characteristics of teats and their associations with risk of clinical mastitis in dairy cows. J. Dairy Sci. 99:8323-8329. https://doi.org/10.3168/jds.2015-10093.

Hogan, J. S., G. L. Bowman, D. E. Pritchard, B. L. Brockett, L. E. Heider, W. D. Hueston, K. H. Hoblet, K. L. Smith, P. S. Schoen- berger, and D. A. Todhunter. 1989. Bacterial counts in bedding materials used on nine commercial dairies. J. Dairy Sci. 72:250258.

Hogan, J. S., R. Gonzalez, R. Harmon, S. Nickerson, S. Oliver, J. Pankey, and K. Smith. 1999. Laboratory Handbook on Bovine Mastitis. National Mastitis Council, Madison, WI.

Makovec, J. A., and P. L. Ruegg. 2003. Results of milk samples submitted for microbiological examination in Wisconsin from 1994 to 2001. J. Dairy Sci. 86:3466-3472.

Mein, G., F. Neijenhuis, W. Morgan, D. Reinemann, J. Hillerton, J. Baines, I. Ohnstad, M. D. Rasmussen, L. Timms, and J. Britt. 2001. Evaluation of bovine teat condition in commercial dairy herds: 1. Non-infectious factors. Pages 347-351 in Proc. 2nd AABP-NMC International Symposium on Mastitis and Milk Quality, Vancouver, BC, Canada. NMC, Madison, WI.

Neijenhuis, F., H. W. Barkema, H. Hogeveen, and J. P. Noordhuizen. 2001a. Relationship between teat-end callosity and occurrence of clinical mastitis. J. Dairy Sci. 84:2664-2672.

Neijenhuis, F., G. Mein, J. Britt, D. Reinemann, J. Hillerton, R. Farnsworth, J. Baines, T. Hemling, I. Ohnstad, N. Cook, W. F. Morgan, and L. Timms. 2001b. Evaluation of bovine teat condition in commercial dairy herds: 4 . Relationship between teat-end callosity or hyperkeratosis and mastitis. Page 362-366 in Proc. 2nd AABPNMC International Symposium on Mastitis and Milk Quality, Vancouver, BC, Canada. NMC, Madison, WI.

Oliveira, L., C. Hulland, and P. L. Ruegg. 2013. Characterization of clinical mastitis occurring in cows on 50 large dairy herds in Wisconsin. J. Dairy Sci. 96:7538-7549.

Pinzón-Sánchez, C., and P. L. Ruegg. 2011. Risk factors associated with short-term post-treatment outcomes of CM. J. Dairy Sci. 94:3397-3410.

Pyörälä, S. 2002. New strategies to prevent mastitis. Reprod. Domest. Anim. 37:211-216.

Rowbotham, R. F., and P. L. Ruegg. 2016. Associations of selected bedding types with incidence rates of subclinical and clinical mastitis in primiparous Holstein dairy cows. J. Dairy Sci. 99:47074717 .

Ruegg, P. L. 2011. Managing mastitis and producing high quality milk. Chapter 18 in Dairy Cattle Production Medicine. C. Risco and P. Melendez, ed., Wiley-Blackwell Publishing, LTD, Hoboken, NJ.

SAS Institute. 2011. SAS/STAT User's Guide. Version 9.3. SAS Institute Inc., Cary, NC.

Ruegg, P. L. 2012. New perspectives in udder health management Vet. Clin. North Am. Food Anim. Pract. 28:149-163. 
Ruegg, P. L., and R. J. Erskine. 2014. Mammary gland health. Pages 1015-1043 in Large Animal Internal Medicine. 5th ed. Mosby Elsevier, St. Louis, MO.

Schreiner, D. A., and P. L. Ruegg. 2003. Relationship between udder and leg hygiene scores and subclinical mastitis. J. Dairy Sci. $86: 3460-3465$.

Schukken, Y. H., J. Gunther, J. Fitzpatrick, M. C. Fontaine, L. Goetze, O. Holst, J. Leigh, W. Petzl, H. J. Schuberth, A. Sipka, D. G. Smith, R. Quesnell, J. Watts, R. Yancey, H. Zerbe, A. Gurjar, R. N. Zadoks, and H. M. Seyfert. 2011. Host-response patterns of intramammary infections in dairy cows. Vet. Immunol. Immunopathol. 144:270-289.

Seegers, H., C. Fourichon, and F. Beaudeau. 2003. Production effects related to mastitis and mastitis economics in dairy cattle herds. Vet. Res. 34:475-491.

Seykora, A. J., and B. T. McDaniel. 1985. Udder and teat morphology related to mastitis resistance: A review. J. Dairy Sci. 68:2087-2093.

Shook, G. E. 1993. Genetic improvement of mastitis through selection on somatic cell count. Vet. Clin. North Am. Food Anim. Pract. 9:563-581.
Slettbakk, T., A. Jørstad, T. B. Farver, and J. C. Holmes. 1995. Impact of milking characteristics and morphology of udder and teats on clinical mastitis in first-and second-lactation Norwegian cattle. Prev. Vet. Med. 24:235-244.

Tucker, C. B., and D. M. Weary. 2004. Bedding on geotextile mattresses: How much is needed to improve cow comfort? J. Dairy Sci. 87:2889-2895.

Vanderhaeghen, W., S. Piepers, F. Leroy, E. Van Coillie, F. Haesebrouck, and S. De Vliegher. 2015. Identification, typing, ecology and epidemiology of coagulase negative staphylococci associated with ruminants. Vet. J. 203:44-51.

Zwertvaegher, I., S. De Vliegher, B. Verbist, A. Van Nuffel, J. Baert, and S. Van Weyenberg. 2013. Short communication: Associations between teat dimensions and milking-induced changes in teat dimensions and quarter milk somatic cell counts in dairy cows. J. Dairy Sci. 96:1075-1080. 